\title{
Abundance and Species Composition of Cave Bats (Mammalia: Chiroptera) in Selected Key Biodiversity Areas (KBAs) of Central Visayas, Philippines
}

\author{
${ }^{1)}$ Gilbert A. Bejec, ${ }^{2 *}$ Lilibeth A. Bucol, ${ }^{3)}$ Tomas D. Reyes, ${ }^{3)}$ Reizl P. Jose, ${ }^{3)}$ Agustin B. \\ Angcog, ${ }^{4)}$ Albert C. Pagente, ${ }^{2)}$ Josie M. Rodriguez, ${ }^{1}$ Anna Lee N. Bejec, \\ ${ }^{1)}$ Neri Fretz P. Paglinawan \\ 1) Cebu Technological University, Argao Campus, Argao, Philippines \\ 2) Negros Oriental State University, Dumaguete, Philippines \\ ${ }^{3)}$ Bohol Island State University, Bilar Campus, Bilar, Philippines \\ ${ }^{4)}$ Siquijor State College, Larena, Philippines. \\ ${ }^{*}$ Corresponding author: Lilibeth A. Bucol, lilibethabs2013@gmail.com
}

\begin{abstract}
This study assessed the abundance and species richness of bats (Order Chiroptera) inhabiting caves in three KBAs (Key Biodiversity Areas) of Central Visayas: Mt. Bandilaan in Siquijor (13 caves), Mabinay, Negros Oriental (11 caves), and Rajah Sikatuna Protected Landscape(RSPL) in Bohol (31 caves). The study was conducted between February 14 to September 20, 2019. Of the 55 caves surveyed, 35 caves were inhabited by bats. Field survey methods included mist-netting at the cave entrances and direct observations of roosting sites in each cave. This study captured 754 individuals of bats belonging to 16 species, majority of which are insectivorous species (13 species) and only three species are fruitbats (Pteropodidae). Mabinay caves had the highest number of species (11) and captured bats (271 individuals) while RSPL had 9 species (221 individuals) while Mt. Bandilaan only had five species but relatively high captured bats (262 individuals). Five species are Philippine endemics (Hipposideros obscurus, Hipposideros pygmaeus, Ptenochirus jagori, Rhinolophus inops, and R. rufus) and three Near-threatened species (H. lekaguli, M. schreibersii, and $R$. rufus). The rare bat species (Dobsonia chapmani) may be locally extirpated in Mabinay, where it last documented at Mambajo cave in the 1960s. The survey also noted the absence of fruit bats (observed in 2011 study) in all of the caves in Mt. Bandilaan, probably due to on-going anthropogenic activities (treasure hunting, bat hunting, guano extraction, land conversion, locals illegal entry, graffiti, etc) in caves surveyed. Large colonies of fruitbats and insect bats in RSPL may have been affected by anthropogenic activities inside the caves. Most of the caves surveyed have been promoted for ecotourism activities.
\end{abstract}

Keywords: cave; chiropteran; extraction; karst; limestone

(Article History: Received 12-11-2020; Accepted 27-04-2021; Published 27-04-2021)

\section{INTRODUCTION}

Bats (Order Chiroptera) are very important because of their diverse ecological functions (Kunz et al., 2011). Aside from being a source of food in some localities, they also serve as prey items for some vertebrate species (Mikula et al., 2016). Some bat species also feed on insects (Balete, 2010), thereby limiting insect pests in agroforestry system (Williams-Guillén et al., 2008). They are also well-known for their role as pollinators (Hodgkison et al., 2003) and therefore play a significant role in forest ecology and also in agroforestry. Bats may also roost in groups inside caves (Sedlock et al., 2014; Tanalgo \&
Tabora, 2015) and their guano deposits have been collected for use as fertilizers (Sothearen et al., 2014).

A number of studies have been done on the cave roosting bats in the Philipines. Tanalgo \& Tabora (2015) documented 14 bat species in the South central Mindanao. In Panay Island, Mould (2012) found 12 bat species in 19 out of the 21 caves surveyed. Sedlock et al. (2014) surveyed the cave bats in Rajah Sikatuna Protected Landscape (RSPL) in Bohol Island, central Philippines. They documented 14 taxa in 23 out of 25 caves that they surveyed. In central Negros Island, Tababa et al. (2012) identified 15 bat species in four caves. 
The study aims to assess the abundance and bat species composition in selected caves of Key Biodiversity Areas (KBAs) in Central Visayas, central Philippines. Such information is highly needed to develop appropriate conservation strategies for cave-dwelling bats.

\section{MATERIALS AND METHODS}

\section{Study Areas}

\section{Mt. Bandilaan Natural Park, Siquijor}

The Mt. Bandilaan Forest Ecosystem has 271 hectares of lowland forest under the management of the Provincial Environment \& Natural Resources (PENRO) and the Protected Areas and Wildlife Bureau (PAWB). The caves in Bandilaan were surveyed from February 16-25, 2019. These caves are being promoted by the local government for eco-tourism. The research team surveyed 13 caves in Siquijor (Appendix 1). The highest cave ceiling height reaches to almost $20 \mathrm{~m}$ and the lowest is at $1.866 \mathrm{~m}$ for Cang-anhao cave and Bung-aw cave, respectively.

\section{Mabinay, Negros Oriental}

The municipality of Mabinay in Negros Oriental is gaining popularity because of their more than four hundred caves. In fact, the said municipality is also known as "The Cave Capital of the Philippines". The area is a karst limestone and rolling landscape characterized by numerous caves and underground river systems (Alcala et al., 2007). The surveyed caves were located in the four barangays of said municipality, namely; Bulwang, Lamdas, Namangka and Paniabonan. A total of 11 caves were surveyed from April 23-May 03, 2019 (Appendix 1). The heights of the ceiling on these caves could reach to $10 \mathrm{~m}$ and chambers measuring more than $15 \mathrm{~m}$ in diameter. Mambajo has a perennial underground river that periodically floods during rainy seasons, while the rest of caves lack this feature. Many large caves in Mabinay (including the cave study sites) are presently used for cave eco-tourism activities by the local government of Mabinay Municipality.

\section{Rajah Sikatuna Protected Landscape (RSPL), Bohol}

RSPL covers an area of 10,452.6 hectares of lowland forested limestone hills with springs and caves. It is the largest of the remaining forests on Bohol Island. Our research team surveyed 31 caves within the
RSPL as listed in Appendix 1. These caves are situated in five (5) municipalities out of seven (7) anchored municipalities within the premises of RSPL, namely; Batuan, Bilar, Carmen, Dimiao, Sierra Bullones and Valencia. The said cave survey started July 24 to September 20, 2019. Elevation of these caves ranges from 362.21 (Palabyo cave) to 571.51 (Bagacay 2 cave) meters above sea level (masl).

\section{Data Gathering}

Prior to fieldwork, the survey team coordinated with the corresponding local government units and the Department of Environment \& Natural Resources (DENR) Offices in Siquijor, Negros Oriental, and Bohol provinces. Caves were surveyed based on standard spelunking safety protocols. To capture bats, two types of mist netting was being deployed (stationary and mobile mist netting) using $3 \mathrm{~m} \times 1 \mathrm{~m}$ mist nets and then were set up near the cave entrance/s. Other team members also searched the inner chambers for the presence of roosting bats. When roost was present, the researchers counted the approximate number of individuals to species level, if possible. However, reconnaissance survey was made into each cave prior to sampling activity. Captured individuals were identified to species level based on Heaney et al. (2010) and Ingle \& Heaney (1992) then marked adopting "marked - and - recapture technique" of C.J.G. Petersen and immediately released back into the wild right after taking all information like age, sex, morphometric, etc.

\section{Data Analysis}

Data were presented in terms of the number of captured bats per species in each cave. To compare counts of captured bats between islands (as groups), data were subjected to non-parametric Kruskall-Wallis test (significance level set at $p<0.05$ ). To visualize similarity of bat species composition, data matrix was transformed into binary data, presence (coded as 1 ) or absence (coded 0) then subjected to cluster analysis ( using the software PAST3 (Hammer et al., 2001). In this analysis, we used the Jaccard Similarity Index and paired group (UPGMA) as the algorithm. Clusters were visually determined based on the resulting dendrogram. To test the hypothesis that these 
three clusters are distinct, One Way-Analysis of Similarity (ANOSIM) was used. Higher R values (from 0 to 1 ) and $\mathrm{p}$ values $<0.05$ suggest that this separation (between clusters) is statistically significant. To differentiate between the clusters, pair-wise comparisons were made. To determine which of the species contributed to any observed differences between clusters, the Similarity of Percentage (SIMPER) test was used.

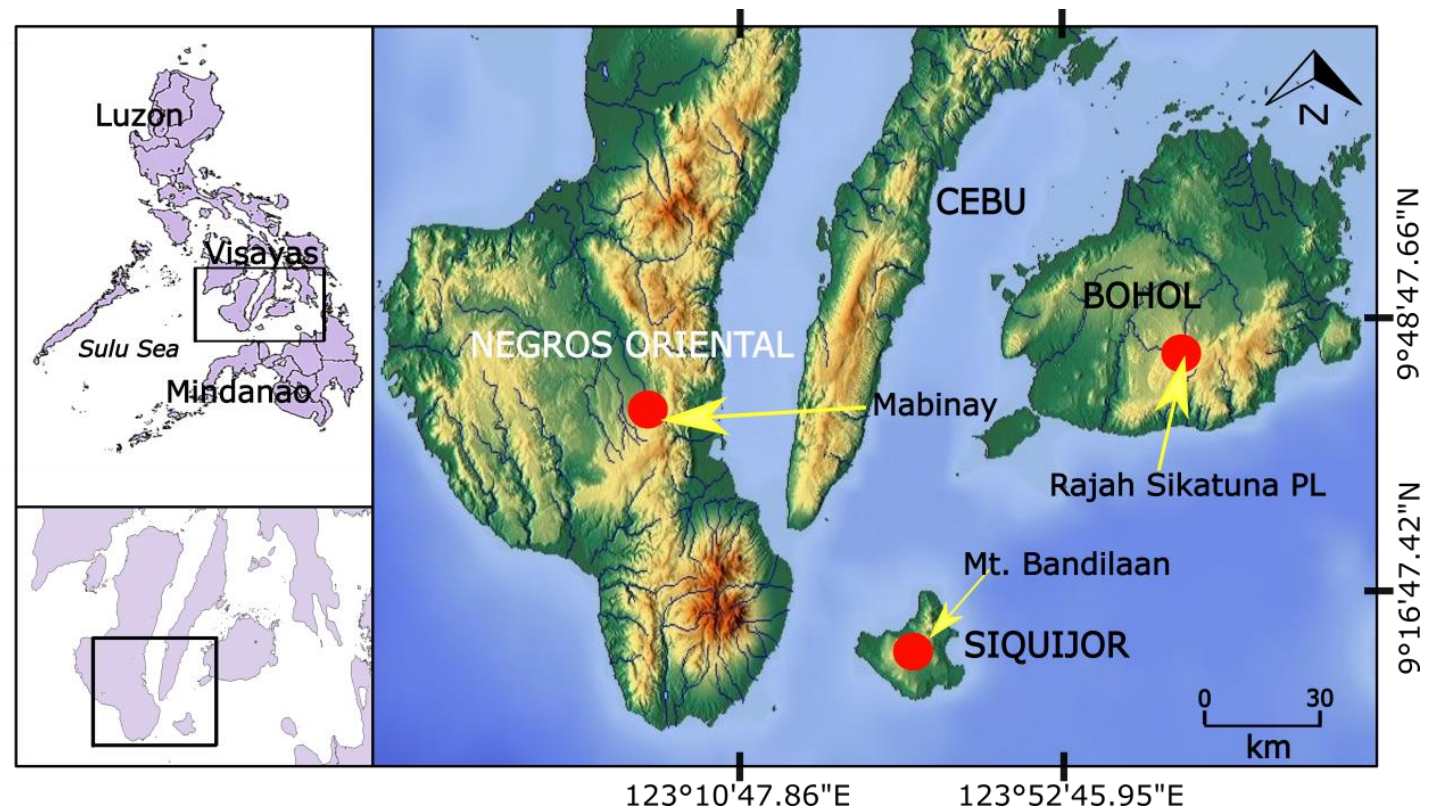

Figure 1. Map of Central Visayas showing the location of the sites surveyed. Base maps derived from PhilGIS (www.philgis.org) and https://maps-for-free.com/.

\section{RESULTS AND DISCUSION}

\section{Results}

This study conducted a more comprehensive survey on cave-dwelling bats in the three Key Biodiversity Areas (KBAs) in Central Visayas, namely Siquijor (13 caves), Negros Oriental (11 caves), and Bohol (31 caves). In all 53 caves surveyed, 754 individual bats were captured belonging to 16 species, 13 species are insectivorous and only three species of fruit bats (Pteropodidae: Cynopterus brachyotis, Ptenochirus jagori and Eonycteris spelaea). Five species are Philippine endemics (Hipposideros obscurus, Hipposideros pygmaeus, Ptenochirus jagori, Rhinolophus inops, and $R$. rufus) and three Near-threatened species ( $H$. lekaguli, $M$. schreibersii, and $R$. rufus). Detailed accounts of abundance (expressed as number of individuals captured) and species richness for each province are provided in the succeeding sections.

\section{Mt. Bandilaan Natural Park, Siquijor Island}

This survey documented 262 individual bats belonging to five species in four families (Hipposideridae, Megadermatidae, Rhino- lophidae, and Vespertilionidae) from 13 caves within the Bandilaan Natural Park (Fig. 2). All five species were present in Cang-anhao Cave, of which Hipposideros diadema dominated the mistnetted individuals (151 out of the estimated maximum count of around 1,000 individuals roosting in this cave). This was followed by Ambakag - baki nature spring cave with 57 individuals mistnetted, 44 of which belong to Miniopterus australis while 13 individuals belong to Rhinolophus arcuatus). In Tugok cave, 22 individuals of Hipposideros obscurus were documented. There were no bats observed inside the rest of the caves, probably due to anthropogenic activities (e.g. treasure hunting). 


\section{Siquijor Cave Bats}

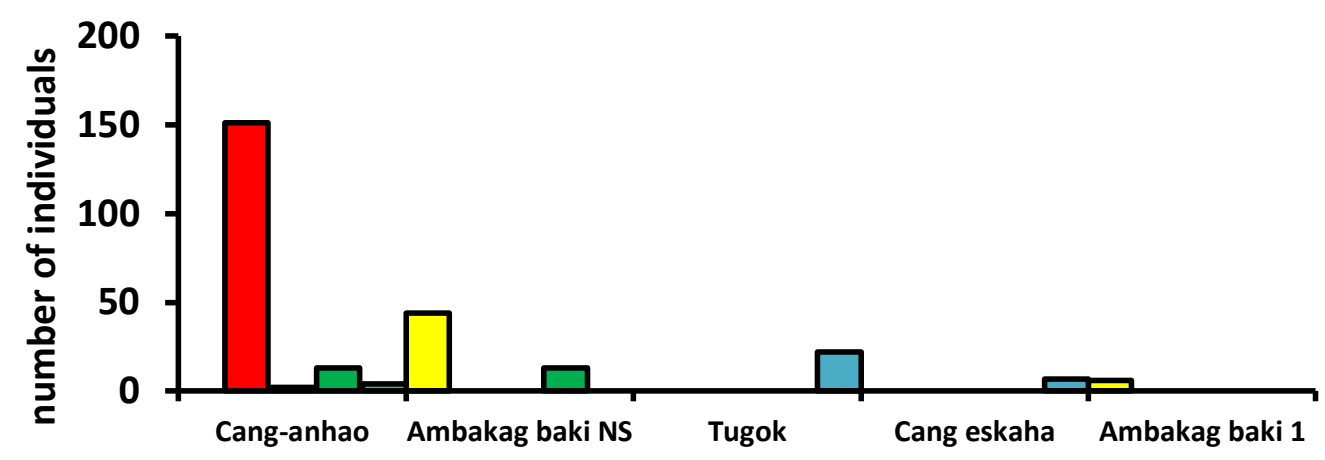

\footnotetext{
口Hipposideros obscurus $\mathbf{\square}$ Hipposideros diadema Miniopterus australis

口Rhinolophus arcuatus $\boldsymbol{\square}$ Megaderma spasma
}

Figure 2. Abundance of cave dwelling bat species in Bandilaan Natural Park, Siquijor (the rest of the caves had no bats).

\section{Mabinay, Negros Oriental}

Between April 23-May 03, 2019, the survey team mistnetted a total of 271 individuals of bats belonging to 11 species in four families (Hipposideridae, Pteropodidae, Rhinolophidae, and Vespertilionidae) were observed in the Mabinay caves (Fig. 3). The highest number of mistnetted bats was in Mambajo cave with 116 individuals, dominated by the the fruit bat Eonycteris spelaea (Common Nectar Bat) with 107 individuals. In Kabugan cave 1, a total of 85 individuals belonging to Miniopterus australis were mistnetted while in an adjacent cave, no bat was observed. Other caves visited but not inhabited by bats include Crystal and Toto, probably due to anthropogenic activities.

\section{Rajah Sikatuna National Park (RSPL), Bohol \\ In the caves of RSPL (Fig. 4), a total of} 221 individual bats belonging to 9 species were recorded, the highest number of captured bats was in Canlusong cave 1 with 53 individuals followed by Cadabas cave with 29 individuals and Buhong Anghit cave with 23 individuals. The rest of the 31 caves in RSPL were represented by below 20 individuals while eight of the caves had no bat inhabitant. Of the 221 bats in these caves, the three species with the highest count were Hipposideros obscurus (55 individuals), $H$. diadema (44 individuals), and Miniopterus australis (33 individuals). The species with the least number of individuals were Megaderma spasma and Rhinolophus arcuatus, with only 7 and 2 individuals, respectively.

\section{Cave Bats Abundance and Distribution Between Island Groups}

Overall, median counts of captured bats did not differ significantly between island groups based on Kruskall-Wallis test ( $\mathrm{p}>$ $0.05)$. However, the two roosting sites $(1,000$ individuals in Cang-anhao Cave in Mt. Bandilaan and Mambajo Cave with > 3,000 individuals in Mabinay, Negros Oriental) were not considered in the analysis owing to the difficulty in quantifying mixed-roosting bat species. 


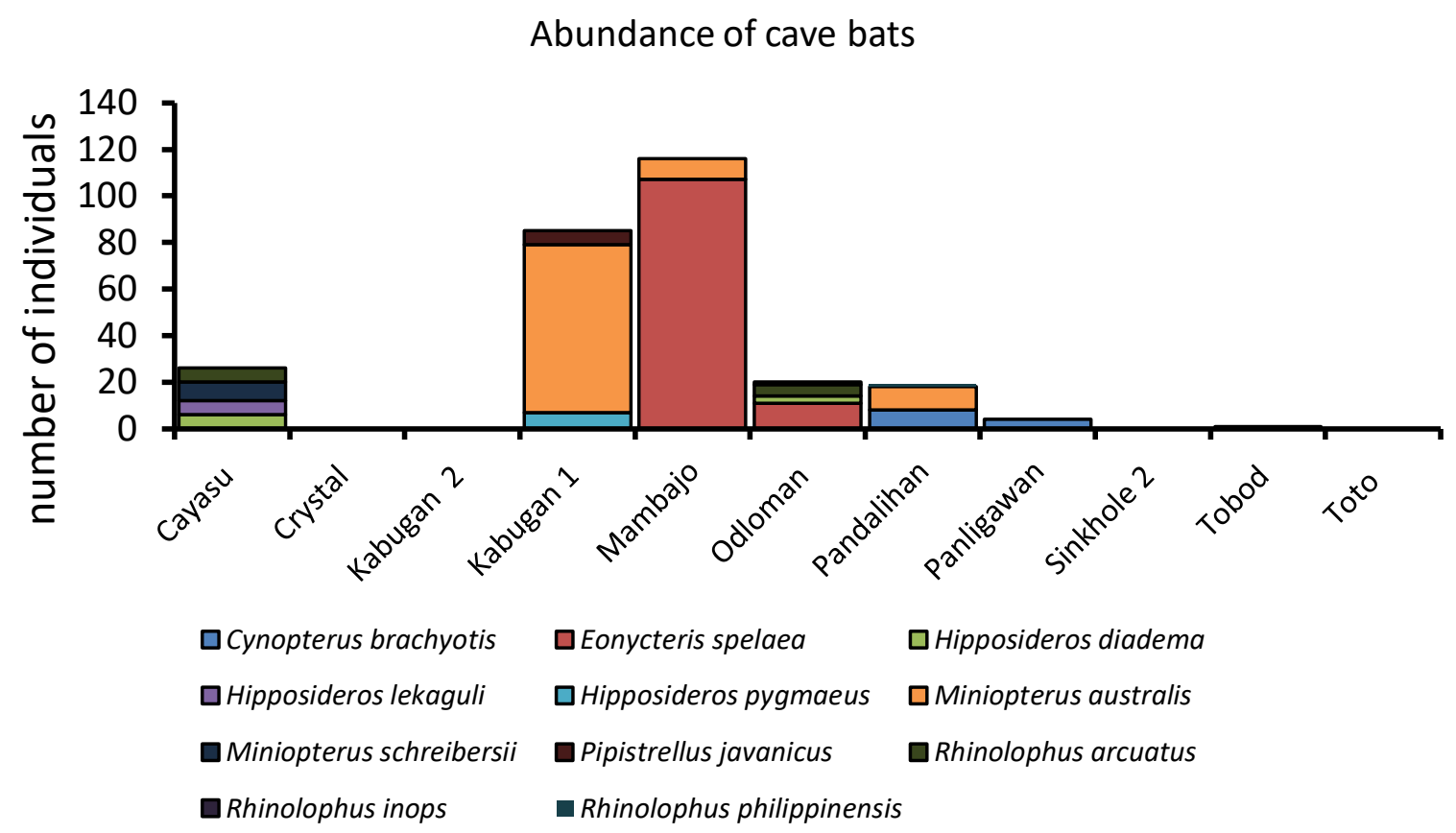

Figure 3. Abundance of cave-dwelling bat species in Mabinay, Negros Oriental.

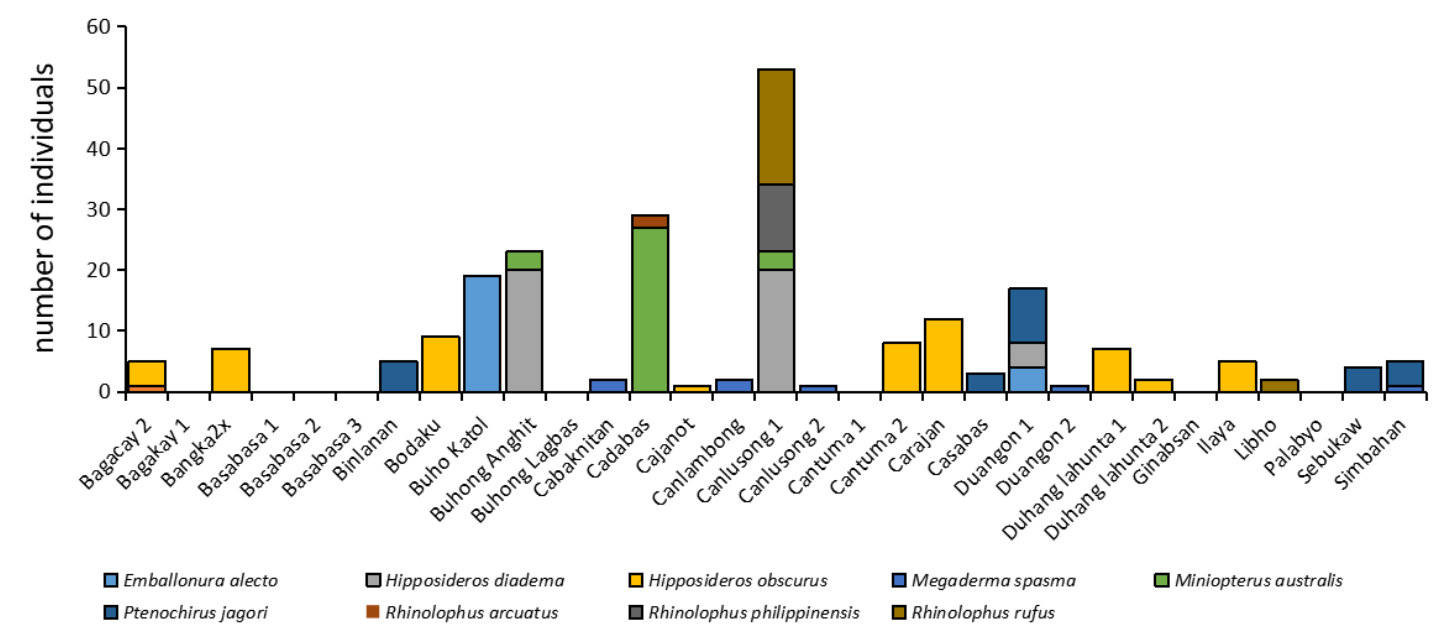

Figure 4. Abundance of cave-dwelling bat species in Rajah Sikatuna Protected Landscape (RSPL), Bohol.

As shown in Fig. 5, three clusters can be shown with strong support $(\mathrm{R}=0.7059 ; \mathrm{p}$ value $=0.0001$ ) based on ANOSIM (using Jaccard Similarity Index). Pairwise comparisons of these clusters were also statistically significant $(\mathrm{p}=0.0001)$ and shows high $\mathrm{R}$ values (>0.5). Clusters 1 and 3 were mainly attributed to Bohol caves with one and two caves from Siquijor, respectively, while Cluster 2 shows an overlap of sites from the three major KBA sites. Subsequent Similarity of Percentage (SIMPER) Analysis revealed that pairwise comparisons between clusters 1 and $3(\mathrm{R}=0.7364)$ and between 2 and $3(\mathrm{R}=$ 0.8321 ) were mainly driven by Hiposiderus obscurus, with $42.31 \%$ and $26.72 \%$, respectively. Pairwise comparison between clusters 1 and 2 was of moderate $R$ value $(0.5328)$ but still statistically significant $(p=$ 0.0001 ) was mainly driven by another insect bat species Miniopterus australis with $17.74 \%$ contribution (Table 1).

The fruitbat species E. spelaea and $C$. brachyotis were found only inside caves on Negros while P. jagori was encountered only in five caves in Rajah Sikatuna Protected 
Landscape (RSPL). Six insectivorous bat species (Hipposideros lekaguli, Hipposideros pygmaeus, Miniopterus schreibersiiii, Pipistrellus javanicus, and Rhinolophus inops) were found only in Negros caves and absent in Siquijor or Bohol. Meanwhile, Emballonura allecto and Rhinolophus rufus were found only in RSPL. All of the five species found in Siquijor are also found either in Bohol or Negros sites.

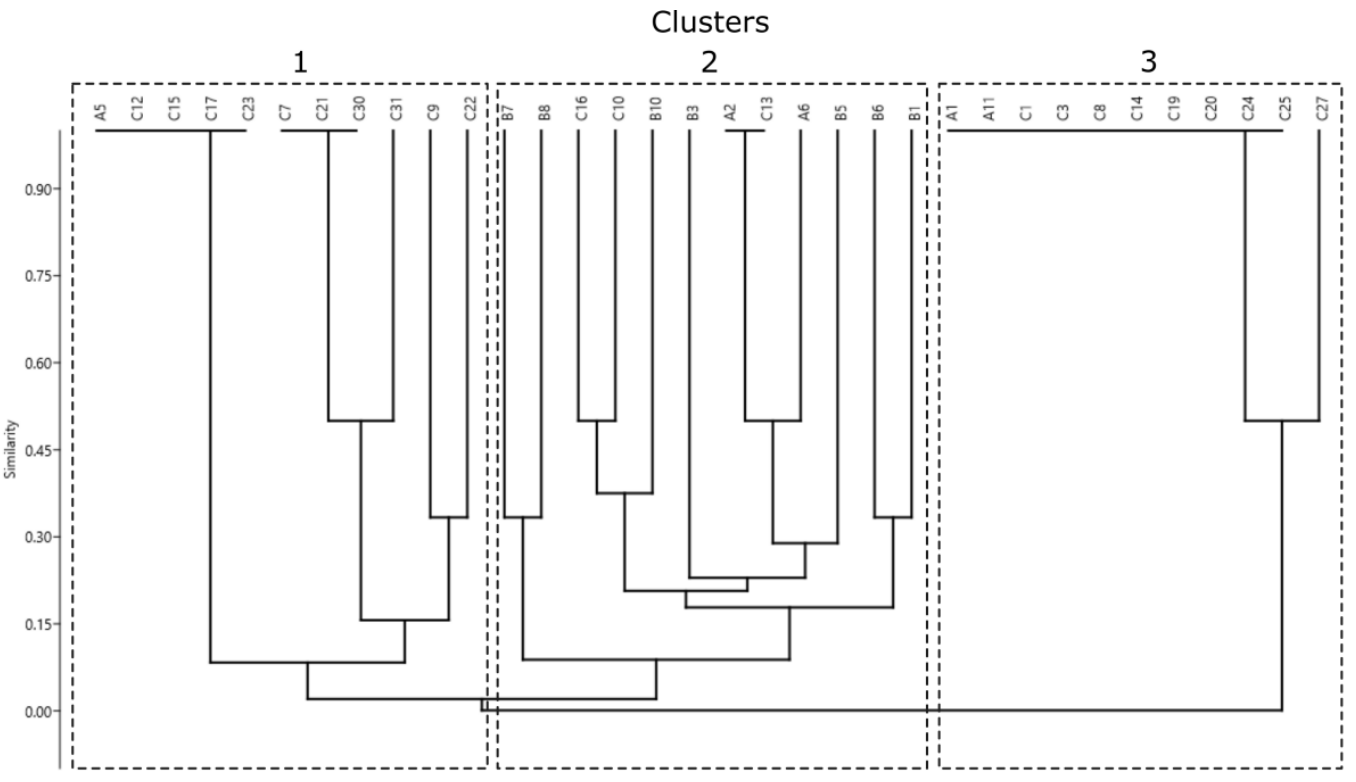

A - Mt. Bandila-an Natural Park, Siquijor Island

B - Mabinay, Negros Oriental

C - Rajah Sikatuna Protected Landscape (RSPL), Bohol

Figure 5. Cluster plot to demonstrate similarity in presence/absence of species cave bats species in selected caves from three KBA sites.

Table 1. Summary of SIMPER and ANOSIM results.

\begin{tabular}{|c|c|c|c|c|c|c|}
\hline \multirow[b]{2}{*}{ Groups } & \multicolumn{3}{|c|}{ SIMPER } & \multicolumn{3}{|c|}{ One-Way ANOSIM } \\
\hline & $\begin{array}{c}\text { Average } \\
\text { Dissimilarity } \\
(\%)\end{array}$ & Discriminating Species & $\begin{array}{c}\text { Contribution } \\
(\%)\end{array}$ & $\mathrm{R}$ value & $\mathrm{p}$ value & significance \\
\hline Cluster 1 vs. 2 & 23 & Miniopterus australis & 17.74 & 0.5328 & 0.0001 & $* * *$ \\
\hline Cluster 1 vs. 3 & 15 & Hipposideros obscurus & 42.31 & 0.7364 & 0.0001 & $* * *$ \\
\hline Cluster 2 vs. 3 & 24 & Hipposideros obscurus & 26.72 & 0.8321 & 0.0001 & $* * *$ \\
\hline
\end{tabular}

significance: $* * *<0.001$

Cluster 1 (A5, C7, C9, C12-17, C21-C23, C30-31)

Cluster 2 (A2, A6, B1, B3, B5-B8, B10)

Cluster 3 (A1, A11, C1, C3, C8, C14, C19-C20, C24-C25, C27)

In all of the caves surveyed $(\mathrm{n}=55)$ in three provinces (Bohol, Negros and Siquijor), the caves in Mabinay had the highest number of bats species with eleven (11) species followed by the caves in RSPL with ten (10) bats species and while Mt. Bandilaan Nature Park in Siquijor only had five (5) species. However, in terms of number in bats family, RSPL had the highest followed Mabinay and Mt. Bandilaan Nature Park at 6 and 4, respectively. Photographs of bats when captured on site are shown in Fig. 6.

\section{Discussion}

This study assessed the cave-dependent bats in three provinces of Central Visayas. This study documented 16 species of bats, majority of which are insectivorous bats with 13 species while fruitbats (Pteropodidae) were represented only by three species (Cynopterus brachyotis, Eonysteris spelaea and Ptenochirus jagori).

The number of species of cave-dwelling bats documented in each study site appears 
lower compared to previous studies done on the cave bats in the Philipines. For example, only five species were observed in Rajah Sikatuna Protected Landscape (RSPL) versus 14 taxa reported by Sedlock et al. (2014) and Phelps et al. (2016) reported 21 species in 56 caves in Bohol. Only 5 species were recorded in 13 caves in Siquijor while Sedlock \& Gomez (2010) recorded 11 species from 20 caves. In Mabinay, this study reported 11 species despite in 11 caves surveyed. Tababa et al. (2012) identified 15 bat species in just four caves. Interestingly, all fruitbats observed in the caves of Mt. Bandilaan by MLR Alcala et al. (2011) were no longer encountered by this study, probably due to continued human disturbance such as guano harvesting and treasure hunting. Tanalgo \& Tabora (2015) documented 14 bat species in the South central Mindanao. In Panay Island, Mould (2012) found 12 bat species in 19 out of the 21 caves surveyed. Alviola et al. (2015) recorded 13 species in 11 caves. Quibod et al. (2019) listed 15 species in 30 caves in Samal Island, Mindanao.

Our survey further confirmed the absence of any rare bat species. Based on IUCN (2019), no threatened species were recorded during the surveys. However, two insectivorous species are considered NearThreatened: 1) Hipposideros lekaguli; and 2) Miniopterus schreibersiii. Hipposideros lekaguli has a very limited distribution in the Philippines (Mindoro and Luzon).

The fruitbat Eonycteris spelaea was observed overlapping roost sites with Eonycteris robusta in one large chamber in 2010 (Tababa et al., 2012) but not observed by this study. Earlier counts made by Alcala et al. (2007) of these species combined in Mambajo cave were placed close to 4,000 individuals, a figure significantly lower than the count estimates $(\sim 7,000)$ in the earlier survey in May 2010. Tababa et al. (2012), however, reported a total bat population of 3,000 in Mambajo Cave. In October 2010, M.L.R. Alcala et al. (2011) showed a significant increase in bat populations with estimates reaching about 50,000 individuals. The increase in the number of bats in Mambajo prior to management interventions by the local government unit has been attributed to the relocation of bat populations coming from other caves. Quarrying, hunting and guano extraction have recently increased in other caves resulting to the transfer cave bats in Mambajo (Alcala et al., 2011). Alcala et al. (2007) noted the absence of the rare, Negros Bare-backed Fruit Bat (Dobsonia chapmani) which used to inhabit Mambajo cave in the 1960 s, probably due to prolonged period of anthropogenic activities leading to the extirpation of this rare bat species. Interestingly, the large roosts of fruitbats (either Rousettus amplexicaudatus or Eonycteris spp.) and thousands of insect bats in caves surveyed by Sedlock et al. (2014) declined during our survey at RSPL. This suggests a negative impact of anthropogenic activities (e.g. guano harvesting and extensive digging) in the past few years.

\section{CONCLUSION}

This study assessed for the first time the abundance and species richness of bats (Order Chiroptera) inhabiting caves in the three KBAs (Key Biodiversity Areas) of Central Visayas: Mt. Bandilaan in Siquijor (13 caves), Mabinay, Negros Oriental (11 caves), and Rajah Sikatuna Protected Landscape in Bohol (31 caves). Of the 55 caves surveyed, between February 14 to September 20, 2019, only 35 caves were inhabited by bats. Using mistnetting at the cave entrances and direct observations of roosting sites in each cave, this study captured 754 individuals of bats belonging to 16 species, majority of which are insectivorous species (13 species) and only three species are fruitbats (Pteropodidae). The caves in Mabinay, Negros Island had the highest number of species (11) and captured bats (271 individuals) while RSPL had 9 species (221 individuals) while Mt. Bandilaan only had five species but relatively high captured bats (262 individuals). The rare bat species (Dobsonia chapmani) may be locally extirpated in Mabinay, where it last documented at Mambajo cave in the 1960s and the lowland forests near caves have been lost already. The survey also noted the absence of fruit bats (observed in 2011 study) in all of the caves in Mt. Bandilaan, probably due to ongoing anthropogenic activities (treasure hunting, bat hunting, guano extraction, land conversion, locals illegal entry, graffiti, etc) in caves surveyed. Large colonies of fruitbats and insect bats in RSPL may have been affected by anthropogenic activities inside the 
caves. Most of the caves surveyed have been promoted for ecotourism activities.

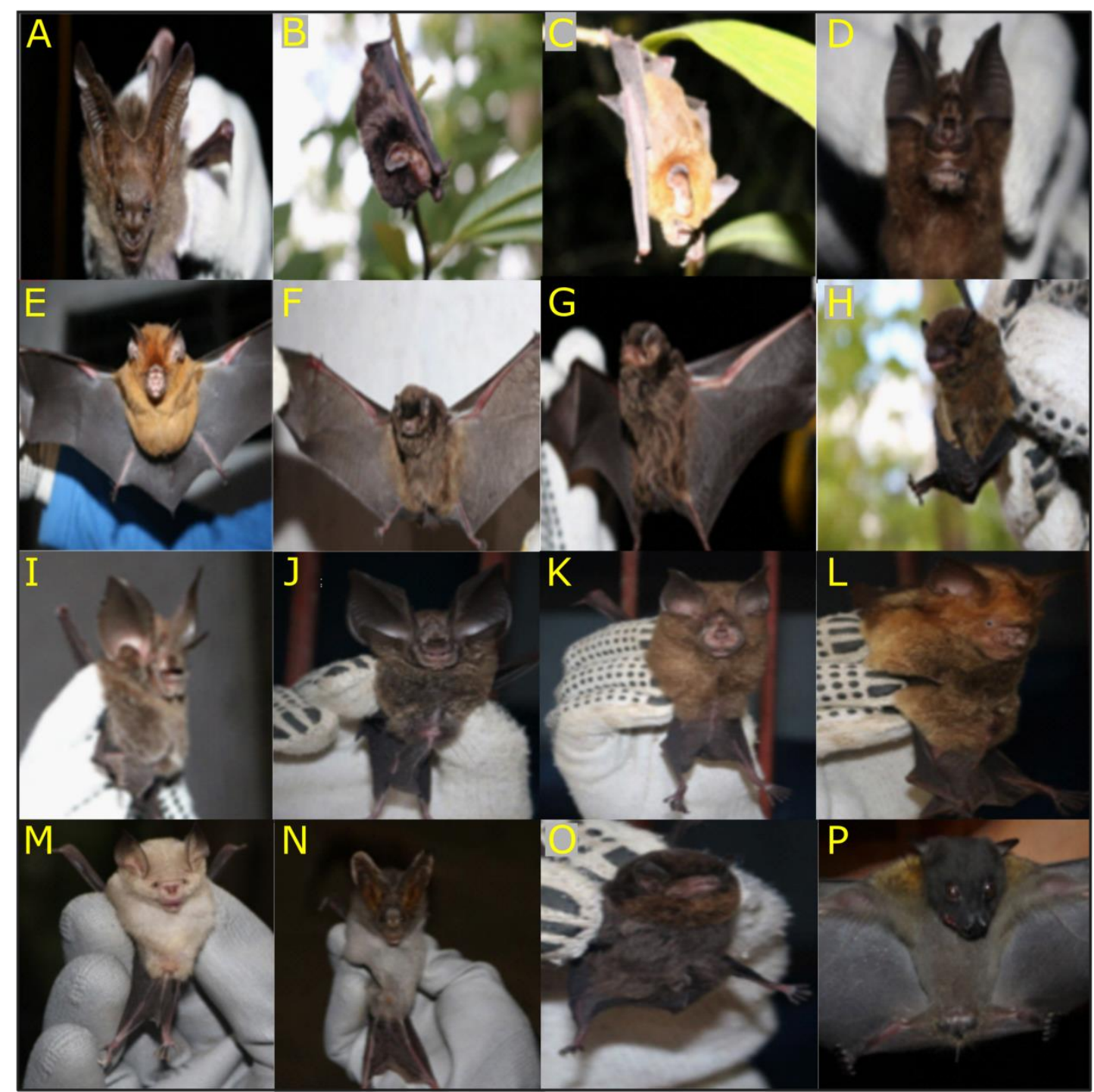

Figure 6. Representative bats photographed in situ during the cave survey in the three key biodiversity areas. From Mt. Bandilaan (A-Megaderma spasma, B-Miniopterus australis, CHipposideros obscurus, D-Rhinolophus arcuatus), Mabinay (E-Hipposideros lekaguli, FMiniopterus schreibersiiii, G-Miniopterus australis, H-Hipposideros diadema, I-Rhinolophus philippinensis), and Rajah Sikatuna Protected Landscape (J-Rhinolophus philippinensis, KRhinolophus rufus, L-Hipposideros diadema, M-Hipposideros obscurus, N-Megaderma spasma, O-Miniopterus australis, P-Ptenochirus jagori).

\section{ACKNOWLEDGEMENTS}

The authors are grateful to DOSTPCAARRD through CVAARRDEC Consortium for funding the research project. Dr. Regucivilla A. Pobar, President, Bohol Island State University (BISU), Dr. Rosein A. Ancheta Jr. President, Cebu Technological University (CTU), Dr. Joel P. Limson, President, Negros Oriental State University (NORSU) and Dr. Imogen T. Quilicot,
President, Siquijor State College, (SSC) are also thanked for their unconditional support on this research project. The respective PAMB (Protected Area Management Board) and DENR (Department of Environment \& Natural Resources) Offices are deeply thanked for their support in issuing the necessary Gratuitous Permits (GPs). We are also indebted to Governor Jecoy Villa of the province of Siquijor and mayors Hon. Ernie T. Uy (former mayor)/Hon. Joetery Uy (mayor) 
of Mabinay Municipality, Negros Oriental, Hon. Manuel G. Jayectin of Bilar Municipality, Bilar, Bohol and Hon. Simplicio Maestrado Jr. of Sierre Bullones of Sierra Bullones, Bohol extending support. Finally, this project would not have been possible without the support of barangay officials from the aforementioned municipalities where we conducted our study.

\section{REFERENCES}

Alcala, E.L., Averia, L., Tababa, L., Dagunan, M.A., Tababa, R., Dasian, J., Libo-on, E.V. \& Ocampo, M. 2007. Assessment of the biophysical condition of caves promoted for ecotourism in Mabinay, Negros Oriental, Philippines. Sil J, 48(1):19-31.

Alcala, M.L.R., Bucol, A.A., Averia, L.T., Alcala, E.L. \& Basa, J.E.P. 2011. Biodiversity and Management Status of Selected Caves in the Visayas, Philippines. A paper presented during the Biodiversity Conference, PICC, Manila, February 1-3, 2011.

Alviola, P.A., Macasaet, J.P.A., Afuang, L.E., Cosico, E.A. \& Eres, E.G. 2015. Cavedwelling bats of Marinduque Island, Philippines. Museum Publ Nat Hist, 4(1): 1-17.

Balete, D.S. 2010. Food and roosting habits of the lesser false vampire bat, Megaderma spasma (Chiroptera: Megadermatidae), in a Philippine lowland forest. Asia Life Sci 4:111-129.

Hammer, Ø., Harper, D.A.T., Ryan, P.D. 2001. Paleontological Statistics Software: Package for Education and Data Analysis. Palaeontol Electron, 4(1):1-9.

Heaney, L.R., Dolar, M.L., Balete, D.S., Esselstyn, J.A., Rickart, E.A. \& Sedlock, J.L. 2010. Synopsis of Philippine mammals. Field Museum of Natural History. Internet resource (http://www. fieldmuseum. org/philippine_mammals/).

Hodgkison, R., Balding, S.T., Zubaid, A. \& Kunz, T.H. 2003. Fruit Bats (Chiroptera: Pteropodidae) as seed dispersers and pollinators in a lowland malaysian rain Forest1. Biotropica 35(4): 491-502.
Ingle, N.R. \& Heaney, L.R. 1992. A key to the bats of the Philippine Islands. Publication (USA): $44 \mathrm{pp}$.

IUCN. 2019. The IUCN Red List of Threatened Species. Version 2019-2. <https://www.iucnredlist.org>. Accessed: October 7, 2019.

Kunz, T.H., Braun, de Torrez E., Bauer, D., Lobova, T. \& Fleming, T.H. 2011. Ecosystem services provided by bats. Ann NY Acad Sci, 1223(1):1-38.

Mikula, P., Morelli, F., Lučan, R.K., Jones, D. N. \& Tryjanowski, P. 2016. Bats as prey of diurnal birds: a global perspective. Mammal Rev, 46(3):160174.

Mould, D.R. 2012. Models for Disease Progression: New Approaches and Uses. Clinical Pharmacology \& Therapeutics, 92(1): 125-131. DOI:10.1038/clpt.2012.53.

Phelps, K., Jose, R., Labonite, M. \& Kingston, T. 2016. Correlates of cave-roosting bat diversity as an effective tool to identify priority caves. Biol Cons, 201: 201-209.

Quibod, M.N.R.M., Alviola, P.A., de Guia, A. P.O., Cuevas, V.C., Lit Jr, I.L. \& Pasion, B.O. 2019. Diversity and threats to cave-dwelling bats in a small island in the southern Philippines. J Asia-Pac Biodiv, 12(4): 481-487.

Sedlock, J.L., Jose, R.P., Vogt, J.M., Paguntalan, L.M.J. \& Cariño, A.B. 2014. A survey of bats in a karst landscape in the central Philippines. Acta Chiropterol, 16(1):197-211.

Sedlock, J.L., Gomez, R.K.S. 2010. Philippine Cave Bats in Crisis? An Assessment of Cave Bats on Siquijor Island. Bat Research News, 51(4): 183184.

Sothearen, T., Furey, N.M. \& Jurgens, J.A. 2014. Effect of bat guano on the growth of five economically important plant species. J Trop Agr, 52(2):169-173.

Tababa, R., Dagunan, M.A., Dejano, B., De La Cruz, S., Gutierrez B., Alcala, E. \& Averia, L. 2012. Preliminary results of the cave bat assessment conducted at Central Negros, Philippines. LCC Dev. Educ. J. Multidiscip. Res 1:85-99. 
Tanalgo, K.C. \& Tabora, J.A.G. 2015. Cavedwelling bats (Mammalia: Chiroptera) and conservation concerns in South central Mindanao, Philippines. Journal of Threatened TAXA, 7(15). http://doi.org/10. 11609/jott.1757.7.15.8185-8194.

Williams-Guillén K., Perfecto, I. \& Vandermeer, J. 2008. Bats limit insects in a neotropical agroforestry system. Science, 320(5872):70-70. 
Appendix 1. List of caves surveyed in three Key Biodiversity Areas (KBAs) in Central Visayas, Philippines.

\begin{tabular}{|c|c|c|}
\hline Code & Name of Cave/ Site & Remarks \\
\hline A & \multicolumn{2}{|c|}{ Bandilaan Natural Park, Siquijor } \\
\hline 1 & Ambak baki & frequented by tourists \\
\hline 2 & Ambak baki nature spring & frequented by tourists \\
\hline 3 & Campbulawan & No bat observed; treasure hunting activities observed \\
\hline 4 & Campong karaan & No bat observed; treasure hunting activities observed \\
\hline 5 & Cang-skaha & \\
\hline 6 & Cang-anhao & \\
\hline 7 & Dakanay & No bat observed; treasure hunting activities observed \\
\hline 8 & Lunas & No bat observed; treasure hunting activities observed \\
\hline 9 & Tinamnag gabi & No bat observed; treasure hunting activities observed \\
\hline 10 & Toronio & No bat observed; treasure hunting activities observed \\
\hline 11 & Tugok & \\
\hline \multirow[t]{2}{*}{ B } & & abinay, Negros Oriental \\
\hline & Cayasu & frequented by tourists \\
\hline 13 & Crystal & No bat observed; frequented by tourists \\
\hline 14 & Kabugan 2 & \\
\hline 15 & Kabugan 1 & No bat observed \\
\hline 16 & Mambajo & $\begin{array}{l}\text { Known habitat of rare species (Dobsonia chapmani); } \\
\text { large colonies of fruit bats (Eonycteris spp) observed }\end{array}$ \\
\hline 17 & Odloman & \\
\hline 18 & Pandalihan & frequented by tourists \\
\hline 19 & Panligawan & frequented by tourists \\
\hline 20 & Sinkhole 2 & \\
\hline 21 & Tobod & No bat observed \\
\hline 22 & Toto & No bat observed \\
\hline
\end{tabular}

Rajah Sikatuna Protected Landscape, Bohol

23 Bagacay 2

24 Bagakay 1

25 Bangka2x

26 Basabasa 1

27 Basabasa 2

28 Basabasa 3

29 Binlanan

30 Bodaku

31 Buho Katol

32 Buhong Anghit

Guano extraction observed

33 Buhong Lagbas

34 Cabaknitan

No bat observed

No bat observed

No bat observed

No bat observed

No bat observed 
35 Cadabas

36 Cajanot

37 Canlambong

38 Canlusong 1

39 Canlusong 2

40 Cantuma 1

41 Cantuma 2

42 Carajan

43 Casabas

44 Duangon 1

45 Duangon 2

46 Duhang lahunta 1

47 Duhang lahunta 2

48 Ginabsan

49 Ilaya

50 Libho

51 Palabyo

52 Sebukaw

53 Simbahan
Treasure hunting activities observed

Guano extraction observed

Guano extraction observed

No bat observed

No bat observed

Guano extraction observed

No bat observed 